\title{
Kajian Interaksi Sosial Perkampungan Terjepit di Kawasan Gading Serpong (Studi Kasus: Kampung Rumpak Sinang, Tangerang)
}

\author{
Meysia Kurniawan ${ }^{1}$, Surya Gunanta Tarigan ${ }^{2}$ \\ ${ }^{12}$ Program Studi Arsitektur, Universitas Pembangunan Jaya \\ Tangerang Selatan, Banten 15413, Indonesia \\ *Corresponding Author: S. G. Tarigan surya.gunanta@upj.ac.id
}

Received 30 December 2020, Revised 4 March 2021, Accepted 29 March 2021

\begin{abstract}
The development of satellite cities such as Gading Serpong has an impact on the existing kampung located both around and in the middle of Gading Serpong. One of them is Kampung Rumpak Sinang, Tangerang District. The location of Kampung Rumpak Sinang which in the middle of the Gading Serpong area has had many impacts on this kampung from economic, social, to the pattern of social interaction space usage in this kampung. This study examines the social, economic, and the usage of social interaction space of the kampung in the middle of Gading Serpong rapid development. The research method used are literature study, interviews, and observations. Based on the results of the research, it is known that there is a positive impact from the economic side for the community and an increase in the quality of human resources which is very much needed and helps the success of the development of Gading Serpong, then from the social side the various impacts are felt with the migrants to the kampung and there are several changes in the function of the social interaction space in the kampung found
\end{abstract}

Keywords: Urban development, Enclaved kampung, Tangerang, Space for social interaction

\begin{abstract}
Abstrak - Perkembangan kota mandiri seperti Gading Serpong berdampak kepada perkampungan eksisting yang berada baik di sekitar maupun di tengah kawasan tersebut. Salah satunya adalah Kampung Rumpak Sinang, Kabupaten Tangerang. Lokasi kampung yang berada di tengah kawasan Gading Serpong memberikan banyak dampak pada kampung ini baik dari dampak ekonomi, sosial, hingga pola penggunaan dan pemanfaatan ruang interaksi sosial. Penelitian ini dimaksudkan untuk menganalisis dampak sosial, ekonomi, serta penggunaan ruang interaksi sosial kampung di tengah jepitan kawasan mandiri. Metode penelitian yang digunakan adalah studi literatur, wawancara, dan observasi lapangan. Berdasarkan hasil penelitian, diketahui bahwa terdapat dampak positif dari sisi perekonomian warga dan peningkatan kualitas sumber daya manusianya yang ternyata sangat dibutuhkan dan membantu kesuksesan dari pengembangan kawasan mandiri, kemudian dari sisi sosial berbagai dampak dirasakan dengan munculnya pendatang pada kampung dan terjadi beberapa perubahan fungsi ruang kampung yang ditemukan.
\end{abstract}

Kata Kunci: Perkembangan kota, Perkampungan terjepit, Tangerang, Ruang interaksi sosial.

\section{PENDAHULUAN}

Pertumbuhan penduduk DKI Jakarta yang terus meningkat memaksa warga Jakarta beralih ke pinggiran Jakarta untuk mendapatkan perumahan yang masih terjangkau dan layak. Salah satu yang menjadi favorit adalah kabupaten Tangerang yang ditandai dengan masifnya pembangunan kawasan terpadu dengan skala kota di kabupaten Tangerang dan Tangerang Selatan. Kota mandiri seperti Bintaro, BSD, Alam Sutera dan Gading Serpong terus mengembangkan kawasannya untuk memenuhi kebutuhan hunian dan investasi bagi warga ibukota. Kota mandiri adalah suatu kawasan yang direncanakan dan dikembangkan tersendiri yang dikembangkan dengan fungsi khusus berkaitan dengan potensi tertentu, secara ekonomi dan sosial dapat memenuhi kebutuhan sebagian besar penduduknya, serta pelayanan infrastruktur dan sistem transportasi umum yang baik (Widodo, 2019).

Kota mandiri yang dibangun oleh pengembang swasta awalnya diharapkan menyediakan perumahan bagi masyarakat menengah kebawah, pada kenyataannya lebih menjadi konsumsi masyarakat menengah keatas (Permanasari, 2006). Salah satu karakteristik pengembangan wilayah yang diambil 
adalah konsep gated community. Leisch (2002) beragumen bahwa gated community menjadi sebuah kebutuhan yang didorong oleh kebutuhan akan keamanan, gaya hidup dan prestise sebuah kawasan. Perkembangan kawasan perumahan dengan skala kota dimungkinkan dengan adanya penguasaan lahan dipinggir kota DKI Jakarta dalam jumlah besar oleh developer swasta (Firman, 2004).

Namun pada beberapa kasus, lahan yang akan dibangun ternyata sudah dihuni oleh masyarakat lokal dengan kepemilikan tanah milik leluhur, sebagai contoh Kawasan Gading Serpong, Kabupaten Tangerang. Kawasan pengembangan yang hanya berjarak $35 \mathrm{~km}$ dari DKI Jakarta ini dikuasai oleh dua perusahaan properti besar yakni PT. Summarecon Agung Tbk dan PT. Paramount Enterprise International. Di kawasan Gading Serpong terdapat beberapa kampung yang telah ada sejak zaman leluhur, salah satunya adalah Kampung Rumpak Sinang, Kelurahan Pakulonan Barat, Kecamatan Kelapa Dua. Lokasi kampung ini berada di tengah kawasan pengembangan Gading Serpong.
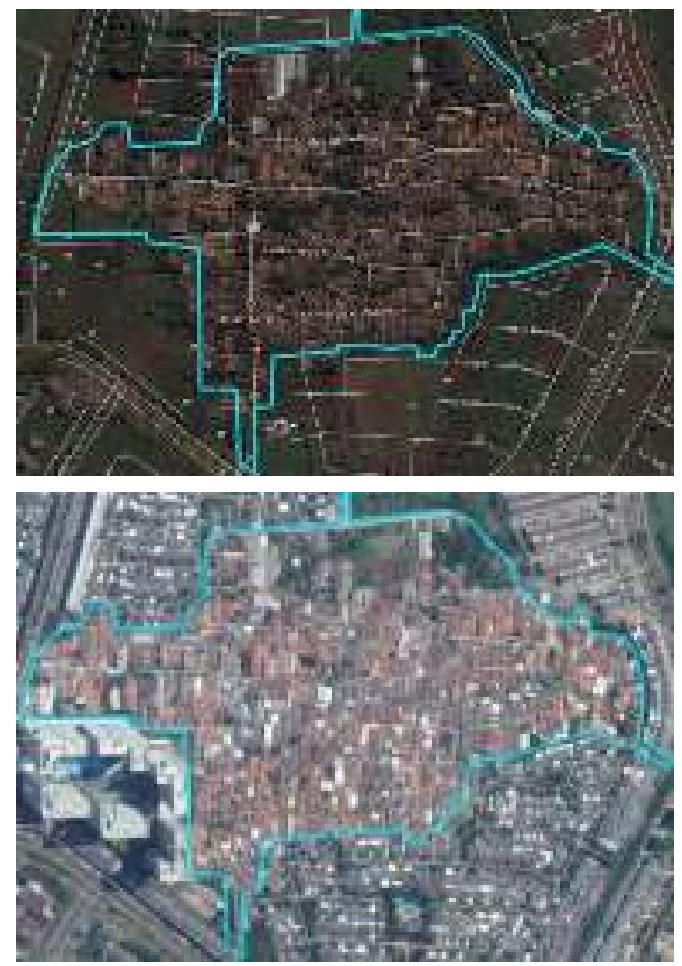

Gambar 1. Citra Satelit Kampung Rumpak Sinang tahun 2004 (atas) dan 2020 (bawah).

Sumber: Google Earth Pro, diolah oleh Penulis, 2020
Terlihat pada gambar 1, Kampung Rumpak Sinang terjepit oleh perkembangan Kawasan Gading Serpong yang mana membuat kampung ini turut merasakan dampak baik dari segi perekonomian, kehidupan sosial, lingkungan. Penelitian ini bertujuan untuk melihat dan menganalisis dampak pembangunan kawasan Gading Serpong terhadap kampung Rumpak Pindang dari sisi sosial ekonomi dan interaksi sosial penduduknya. Adapun pertanyaan penelitian yang akan dibahas adalah:

1. Bagaimana dampak sosial dan ekonomi yang dirasakan oleh masyarakat kampung Rumpak Sinang di tengah kepungan pengembangan kawasan Gading Serpong?

2. Bagaimana pola pemanfaatan ruang interaksi sosial yang muncul pada kampung tersebut?

Penelitian ini diharapkan dapat memberikan gambaran permasalahan perkembangan kota dan menambah pengetahuan yang terkait mengenai fenomena yang diteliti yakni kajian interaksi sosial masyarakat kampung di tengah himpitan pembangunan kawasan dan kota mandiri.

\section{METODE PENELITIAN}

Untuk menganalisis interaksi sosial pada kampung Rumpak Sinang di tengah pengembangan kawasan Gading Serpong, metode yang digunakan oleh peneliti adalah metode kualitatif deskriptif. Pada penelitian ini data primer dikumpulkan melalui wawancara yang bersifat semi terstruktur kepada pengurus RT dan RW kampung Rumpang Sinang dan masyarakat yang bermukim minimal 1 tahun di kampung, kemudian peneliti juga melakukan observasi lapangan yang dimaksudkan untuk meninjau penggunaan ruang interaksi sosial pada kampung Rumpak Sinang yang dibagi menjadi beberapa periode waktu yakni pagi, siang, sore, dan malam.

Penelitian ini juga membahas berbagai dampak sosial ekonomi yang dirasakan, interaksi sosial yang terjadi di kampung Rumpak Sinang, serta analisis ruang interaksi sosial yang muncul dan digunakan oleh masyarakat kampung Rumpak Sinang. Data yang bersumber dari berbagai studi literature dan interview kemudian dibandingkan dengan teori perencanaan kota untuk mendapatkan pemahaman yang lebih jauh akan pengaruh perkembangan wilayah Gading Serpong terhadap kampung terjepit Rumpak Sinang. 
Dikarenakan penelitian ini dilakukan dalam masa Pandemi Covid-19, maka terdapat berbagai kendala dan mitigasi yang harus dilakukan. Salah satunya adalah keterbatasan penulis untuk dapat dengan leluasa melakukan interview dengan masyrakat kampung, namun interview di lapangan tetap dapat dilakukan dengan tetap memenuhi protokol kesehatan dan pencegahan terpaparnya virus seperti menerapkan 3M (mencuci tangan, memakai masker, dan menjaga jarak).

\section{HASIL PENELITIAN DAN ANALISIS}

\section{Dampak Ekonomi}

Berdasarkan hasil wawancara dengan responden, para responden memberikan tanggapan bahwa adanya kawasan Gading Serpong berdampak kepada peningkatan perekonomian warga baik secara langsung maupun tidak langsung. Secara langsung adalah dengan adanya mata pencaharian baru bagi masyarakat kampung. Peningkatan aktivitas ekonomi pada kawasan Gading Serpong juga memberi kemudahan bagi warga kampung untuk mendapatkan pekerjaan di lingkungan perumahan, apartement, shopping mall maupun perkantoran baru di Gading Serpong. Menurut warga, biasanya perangkat kampung melalui RT dan RW turut membantu para warganya untuk dapat bekerja di kawasan Gading Serpong baik menjadi asisten rumah tangga, penjaga keamanan, dan pekerjaan lainnya.

Tabel 1. Daftar Pekerjaan Responden Wawancara

\begin{tabular}{lcl}
\hline Nama & $\begin{array}{c}\text { Jenis } \\
\text { Kelamin }\end{array}$ & Pekerjaan \\
\hline Yuli & $\mathrm{P}$ & $\begin{array}{l}\text { IRT / Istri Ketua } \\
\text { RT 01/02 }\end{array}$ \\
\hline Muklis & $\mathrm{L}$ & $\begin{array}{l}\text { Pekerja Swasta / } \\
\text { Ketua RW 02 }\end{array}$ \\
\hline Mariatin & $\mathrm{P}$ & $\begin{array}{l}\text { ART Kawasan } \\
\text { Gading Serpong }\end{array}$ \\
\hline Ahmad & $\mathrm{L}$ & $\begin{array}{l}\text { Ketua RW 01 / } \\
\text { Driver }\end{array}$ \\
\hline Fadilah & $\mathrm{L}$ & $\begin{array}{l}\text { Pekerja } \\
\text { serabutan (jasa) }\end{array}$ \\
\hline Mustofa & $\mathrm{L}$ & Pedagang \\
\hline Nenden & $\mathrm{P}$ & IRT / Pedagang \\
\hline Adah & $\mathrm{P}$ & IRT \\
\hline Rohati & $\mathrm{P}$ & IRT / Pedagang \\
\hline
\end{tabular}

Keberadaan pembangunan di Gading Serpong juga menambah fungsi-fungsi komersial ruang dari kampung juga dimana munculnya area-area komersial seperti warung dan berbagai toko-toko lainnya, tercatat terdapat kurang lebih 100 pertokoan dan area komersial lainnya yang berada di koridor utama JL. K. H. Musa, Kampung Rumpak Sinang (gambar 2). Salah satu responden yang merupakan seorang pedagang warteg juga mengatakan dengan adanya Gading Serpong dan pembangunan Apartemen MTown beberapa tahun belakangan ini turut memberikan peningkatan pendapatan dari wartegnya.

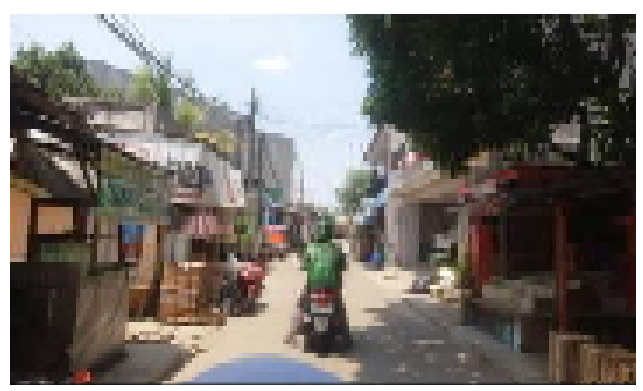

Gambar 2. Koridor Utama Kampung Rumpak Sinang, Sumber: Dokumentasi Pribadi, 2020

Selain itu, muncul banyak sekali kos-kosan dengan kepemilikan $80 \%$ masyarakat luar kampung dan 20\% masyarakat kampung. Munculnya kos-kosan disebabkan oleh peningkatan jumlah penduduk pendatang ke kampung ini mengingat lokasi yang strategis untuk bekerja. Adanya perkampungan di tengah himpitan kawasan mandiri tentunya juga berfungsi cukup penting dan turut memberikan dampak dari suksesnya suatu kota mandiri.

Masyarakat kampung berusaha berkembang melalui berbagai sektor informal seperti membuka warung dan sebagainya. Kampung juga dapat berfungsi sebagai area untuk menampung pekerja dengan upah rendah karena para pekerja tersebut juga mendapatkan pendapatan dari sektor informal lainnya. Sehingga kampung menjadi pilar penting dari suatu kesuksesan dari kapitalisme pada suatu kota.

Dapat disimpulkan bahwa kampung kota merupakan bagian yang sangat penting dalam global capitalism dimana mampu menampung pendudukpenduduk kelas menengah ke bawah yang sumber daya manusia (SDM) sangat dibutuhkan bagi kelangsungan kota namun memiliki tingkat penghasilan yang relatif rendah. Masalah yang banyak dijumpai pada kota-kota pusat bisnis dunia tapi dengan biaya hidup yang sangat tinggi (PWC, 2019). Terpinggirkan tapi penting, kampung merupakan tempat 70 sampai 80 persen populasi kota. Kampung berkembang dan berkontribusi pada kehidupan sosial dan ekonomi (Kusno, 2020). Selain itu menurut beberapa warga, pengelola dan warga Gading Serpong juga sesekali memberikan bantuan berupa sumbangan kepada yatim piatu dan janda ke Kampung Rumpak Pinang. 
Secara tidak langsung, keberadaan kawasan Gading Serpong turut mendongkrak harga tanah di kampung Rumpak Pinang. Menurut salah satu responden, berkembangnya Gading Serpong memberikan dampak positif seperti harga tanah yang dulunya berkisar 100.000 per $\mathrm{m} 2$, sekarang menjadi 2-3 juta per $\mathrm{m}^{2}$. Pihak perusahaan pengembang telah beberapa kali memberi tawaran harga untuk membeli kawasan kampung ini, namun warga kampung bersatu dan tetap mempertahankan tanah leluhur mereka agar tidak jatuh ketangan pengembang. Kampung Rumpak Sinang tetap bersatu dan memegang pesan leluhur mereka yaitu Abuya Musa dan Abuya Sueb untuk tetap menjaga tanah kelahiran mereka dan membangun kampung tersebut (Arbi, 2017).

\section{Dampak Sosial}

Berbagai dampak sosial turut dirasakan oleh masyarakat kampung Rumpak Sinang. Berdasarkan hasil wawancara, terdapat beberapa responden yang mengatakan dengan adanya kawasan Gading Serpong berdampak pada banyaknya pendatang ke kampung ini. Adanya konsep warga pendatang dan warga asli tentunya menjadi topik yang penting dikarenakan warga pendatang yang cenderung kurang dapat berbaur dengan masyarakat 'lokal' yang telah berada di kampung tersebut dan tidak mempunyai ikatan batin yang kuat seperti beberapa responden yang lahir di kampung tersebut. Salah satu responden juga menekankan bahwa menurutnya warga pendatang hanya menjadikan kampung sebagai kawasan tempat mereka tinggal dan jarang sekali bersosialisasi atau datang pada acara dengan warga asli kampung.

Hal yang dibenarkan juga salah satu warga pendatang di kampung yang hanya merasa dekat dengan sesama pendatang dan tidak terlalu dekat dengan penduduk asli kampung. Lebih lanjut menurut salah satu responden biasanya warga pendatang yang tinggal di kontrakan atau kos-kosan hanya memberikan iuran bila ada acara yang akan dilaksanakan tapi jarang mau ikut serta.

Berbicara mengenai pengembangan kawasan mandiri Gading Serpong yang didirikan oleh pihak pengembang juga secara tidak langsung menciptakan spatial segregation yang berada antara kampung dan Gading Serpong. Pembatas yang dibuat oleh perusahaan pengembang membuat masyarakat kampung dan masyarakat Gading Serpong jarang menjalin hubungan interaksi sosial. Berdasarkan hasil wawancara dengan responden, masyarakat Gading Serpong pada umumnya hanya memberikan bantuan pada acara tertentu namun selebihnya tidak ada interaksi intensif yang terjadi. Interaksi memang jarang terjadi karena antara warga kampung juga tidak sering bertemu dengan penghuni kawasan Gading Serpong.

Uniknya, masyarakat kampung seakan mengadopsi kehidupan modern Gading Serpong seperti adanya portal pengaman di pintu masuk utama kampung dan munculnya pos penjaagaan di samping portal (gambar 3). Masyarakat kampung tanpa disadari juga menciptakan gated community-nya dengan alasan keamanan.

Walaupun masyarakat kampung mengadopsi kehidupan masyarakat Gading Serpong dengan adanya konsep baru lingkungan kampung dengan munculnya portal penjagaan dan batasan-batasan yang dibuat antara luar kawasan dan dalam kawasan kampung, tetapi masyarakat kampung masih sangat menjalin hubungan erat satu sama lain.

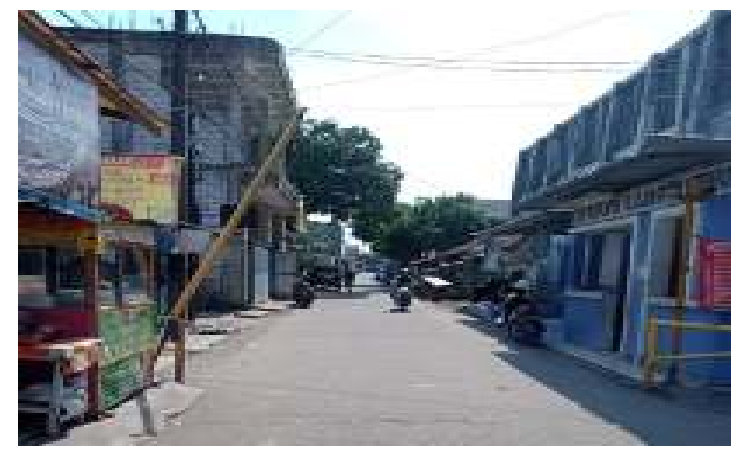

Gambar 3. Area Pintu Masuk Kampung Rumpak Sinang, Sumber: Dokumentasi Pribadi, 2020

Keterikatan antar penduduk masih sangat terasa dengan adanya kegiatan majelis taklim seperti pengajian bersama, kampung Rumpak Sinang pada dahulunya terkenal sebagai kampung santri, dikarenakan banyaknya pesantren dan para santri. Selain itu, acara tahunan seperti 17-an, kerja bakti juga rutin dilakukan oleh penduduk kampung walaupun selama pandemi Covid-19 kegiatan bersama seperti majelis taklim ditiadakan.

Namun beberapa responden mengatakan bahwa walaupun interaksi tetap terjalin, tetapi tidak intensif seperti dulu lagi dikarenakan berbagai faktor akibat dari moderninasi kampung di ruang perkotaan. Mereka merasakan bahwa sekarang warga Kampung semakin sibuk dengan urusannya masing-masing. Selain modernisasi, kurangnya interaksi yang terjadi di lingkungan kampung Rumpak Sinang disebabkan oleh lapangan utama yang sering digunakan dahulu untuk acara bersama, olah raga dan anak-anak bermain sekarang telah berubah menjadi Apartemen M-Town karena tanahnya telah dijual oleh sebagian warga area luar kampung Rumpak Sinang. Akibatnya tidak ada lagi ruang publik yang dapat mewadahi kegiatan bersama, kalaupun ada hanya memanfaatkan lahan kecil yang kosong dan terpisah kegiatannya setiap RT (Rukun Tetangga).

\section{Ruang Interaksi Sosial}

Ruang-ruang interaksi masyarakat kampung Rumpak Sinang di tengah kawasan mandiri Gading Serpong telah banyak mengalami perubahan. Untuk itu, penulis memetakan titik-titik ruang interaksi sosial dengan menganalisis jenis-jenis interaksi yang terjadi dan bagaimana pola pemanfaatan ruang interaksi sosial tersebut. Penulis membagi penjelasan 
ruang interaksi menjadi dua zona yaitu zona koridor jalan utama Jl. K. H. Musa (zona luar) yakni zona komersial, dan zona bagian dalam yakni zona di mana permukiman warga kampung dipusatkan.

\section{Zona Luar}

Pada zona luar atau koridor utama dari Kampung Rumpak Sinang, aktivitas dominan yang dilakukan masyarakat bersifat lebih kepada aktivitas komersial dikarenakan jalan ini merupakan jalan utama bagi masyarakat kampung dan masyarakat luar untuk melintas. Tercatat terdapat kurang lebih 100 pertokoan dengan fungsi berbagai jenis mulai dari kos-kosan, warung makan, pengumpulan sampah berada pada zona ini.

Aktivitas komersial ini muncul dikarenakan lokasi strategis kampung Rumpak Sinang yang berada di tengah-tengah kawasan Gading Serpong, sehingga lokasi ini sangat strategis. Ruang interaksi sosial yang muncul dan tampak dominan terlihat pada area pintu masuk selatan kampung yang terdiri dari beberapa lapak PKL (Pedagang Kaki Lima) mulai dari pukul 08.00-12.00 WIB.

Terdapat juga ruang interaksi yang bersifat tidak tetap dan berubah yakni selasar rumah dan toko warga. Terakhir adalah poros tengah yang terdapat pos penjagaan bagi masyarakat kampung ini dan hanya beroperasi saat malam hari.

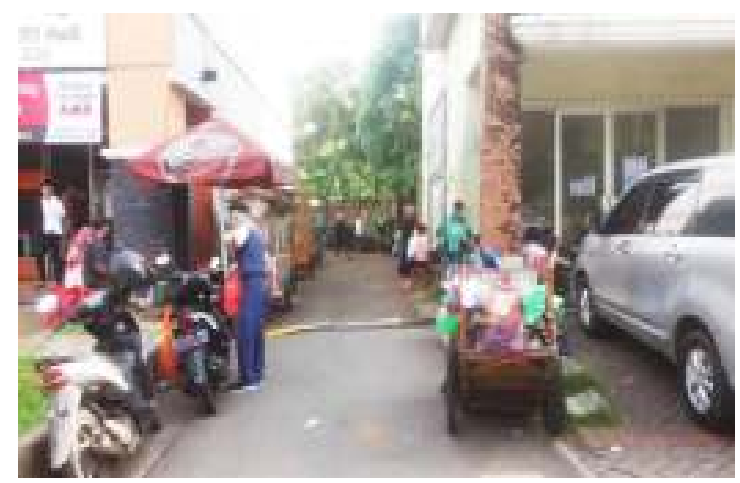

Gambar 4. Pintu Masuk Selatan Kampung Rumpak Sinang Sumber: Dokumentasi Pribadi, 2020

Pada area pintu masuk selatan ini, baik masyarakat kampung maupun luar kampung menjadikan koridor ini sebagai area berjualan bagi para PKL. Jumlah PKL ada enam (6) dengan jenis jualan rata-rata makanan dan minuman. Pengunjung area ini didominasi oleh pekerja ojek online yang sekedar beristirahat pada tempat ini, pekerja pada kawasan Gading Serpong, masyarakat kampung. Dengan adanya kawasan Gading Serpong, koridorkoridor pada jalan kampung dimanfaatkan dengan baik untuk aktivitas komersial.
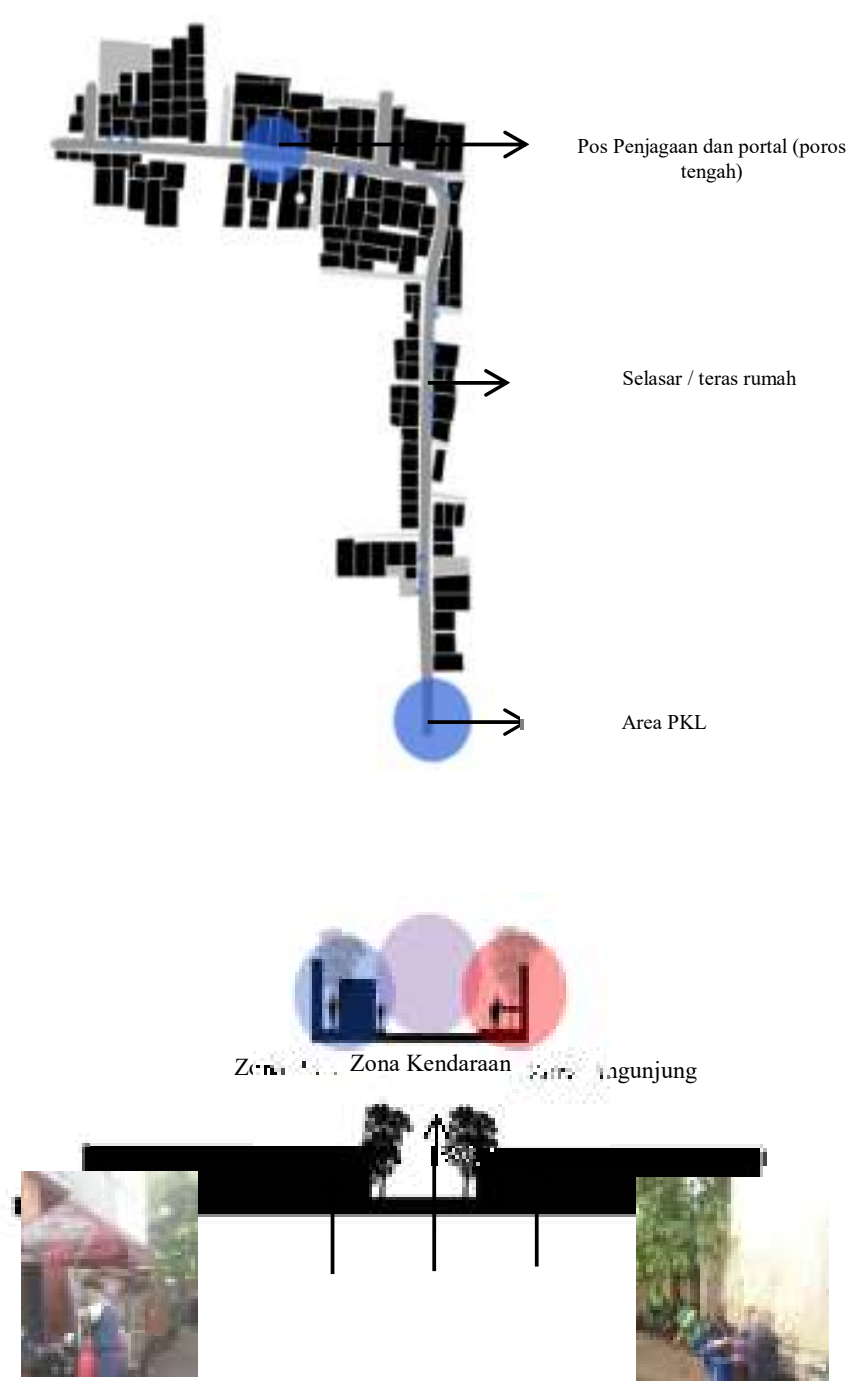

Gambar 5. Pembagian Zona dan Potongan Koridor pada Pintu Masuk Selatan Kampung Rumpak Sinang Sumber: Olahan Pribadi, 2020

Berdasarkan hasil wawancara penulis, terdapat pos penjagaan yang membagi dua RW yakni RW 01 dan RW 02, maka warga menyebutnya sebagai poros tengah. Pos ini terbentuk semenjak tahun 2017-an ketika pembangunan apartemen M-Town berlangsung. Adanya pos tengah ini menjadi ruang interaksi warga antar RW pada malam hari. Kemudian akses masuk setelah pukul 00.00 WIB juga hanya melalui pos ini. Maka dari itu peranan fungsi dari pos ini juga sangat penting. 


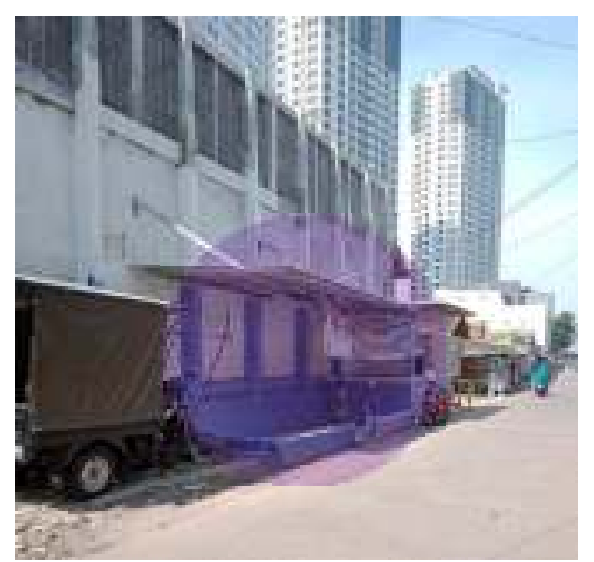

Gambar 6. Poros Tengah Kampung Rumpak Sinang Sumber: Dokumentasi Pribadi, 2020

\section{Zona Dalam}

Pada zona dalam kampung Rumpak Sinang, terdapat beberapa aktivitas interaksi sosial dan menjadi ciri-ciri dari suatu kampung dengan segala nilai tradisionalnya dan ikatan antar kehidupan bertetangga dari warga kampung. Ruang-ruang interaksi yang ditemukan seperti majelis taklim yang cukup banyak, pada periode penelitian ini, peneliti menemukan terdapat sekurang-kurangnya empat (4) lokasi majelis taklim yang berada di kampung Rumpak Sinang. Kemudian terdapat lapangan masing-masing satu (1) tiap RW dan dipergunakan cukup baik pada RW 02, dan terdapat lapangan parkir kantor Kelurahan Pakulonan Barat yang menurut responden, lokasi tersebut biasanya digunakan untuk acara warga bersama. Kemudian peneliti juga menemukan ruang interaksi sosial sepanjang koridor dalam dari kampung ini. Berikut titik-titik lokasi ruang interaksi sosial yang berhasil dipetakan oleh penulis dalam kurun waktu tertentu.

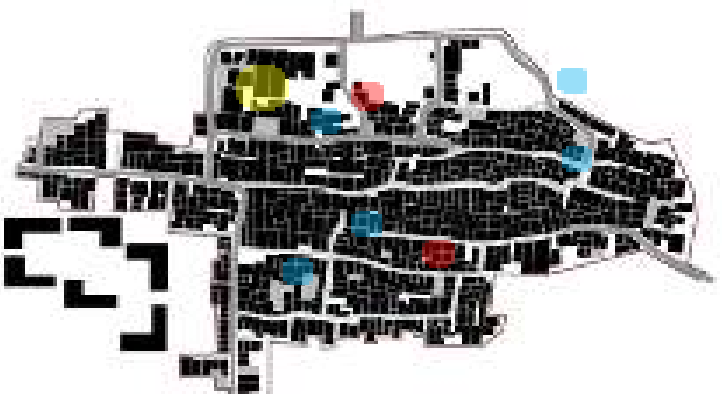

Legenda :

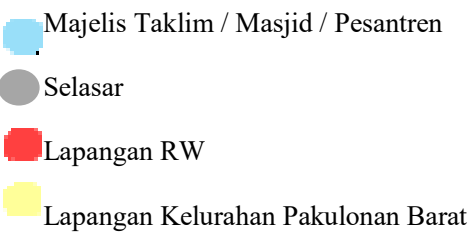

Gambar 7. Figure Ground dan Titik-titik Ruang Interaksi Masyarakat Kampung Rumpak Sinang Sumber: Dokumentasi dan Olahan Pribadi, 2020
Lapangan yang ada di Kampung Rumpak Sinang berjumlah dua (2) lapangan dan berada pada masingmasing RW. Lapangan pada RW 01 (gambar 8) pada umumnya tidak terpakai dan menjadi lapangan parkir. Masyarakat lebih banyak berinteraksi di selasar rumah dan anak-anak bermain di area jalan umum serta selasar. Kondisi lapangan pada RW 01 juga kurang terawat karena akses menuju lapangan yang tertutup oleh tembok pembatas dan terdapat rumputrumput yang dibiarkan tumbuh secara liar pada area lapangan sehingga rasa kepemilikan lapangan menjadi kurang terasa.

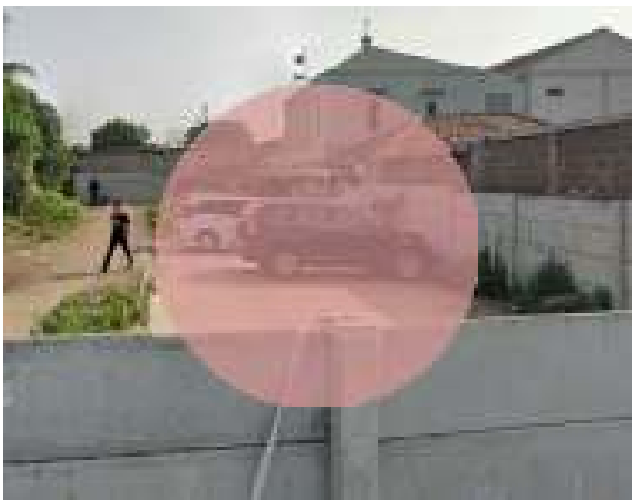

Gambar 8. Lapangan Bersama RW 01 Sumber: Google Maps, 2020
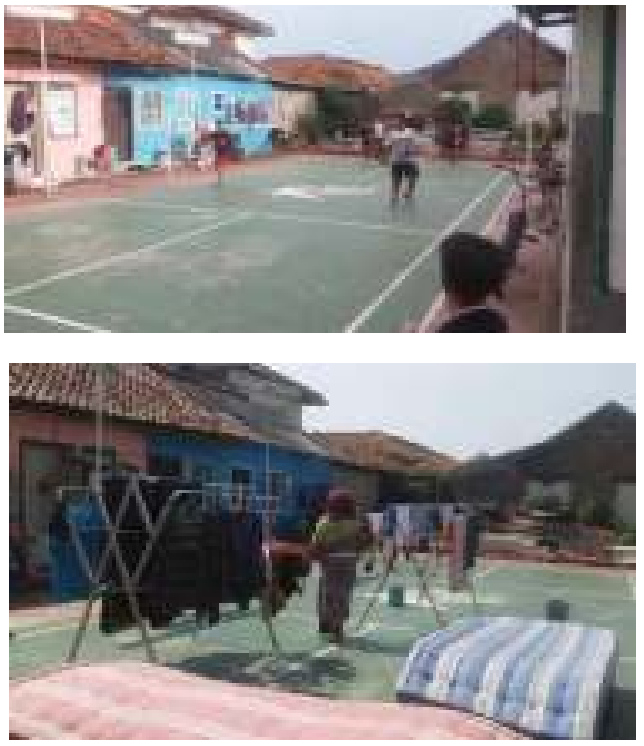

Gambar 9. Lapangan Bersama RW 02 Sumber: Dokumentasi Pribadi, 2020

Pada lapangan pada RW 02 (gambar 9), terlihat aktivitas warga lebih dominan, dimana terdapat berbagai aktivitas di lapangan seperti ibu-ibu yang menjadikan area lapangan sebagai area mengeringkan pakaian, dan pada saat sore hari digunakan sebagai area latihan sepak bola oleh para remaja. Kondisi fisik lapangan juga tampak baik dan mendukung kegiatan. Lapangan pada kantor Kelurahan Pakulonan Barat biasanya digunakan oleh karang taruna untuk melakukan berbagai kegiatan remaja, acara 17-an di 
lapangan ini, dan apabila ada bantuan dari luar kawasan Kampung Rumpak Sinang, warga akan mengambil bantuan mereka di lapangan ini.

\section{MAJEUS TAKLIM KAMPUNG RUMPAK SINANG}

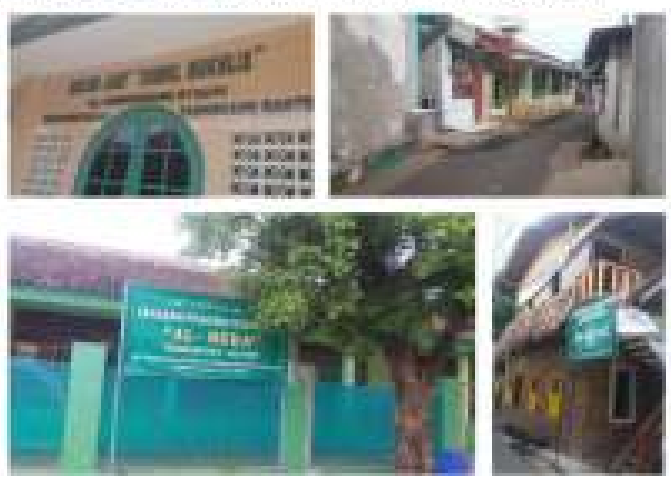

Gambar 10. Majelis Taklim Kampung Rumpak Sinang Sumber: Dokumentasi Pribadi, 2020

\section{Majelis Taklim}

Pada zona dalam, juga terdapat ruang interaksi di masjid dan juga majelis taklim yang ditemukan pada kampung Rumpak Sinang. Kampung ini dahulu merupakan kampung yang dikenal sebagai kampung santri karena jumlah pesantren dan santri yang cukup banyak. Hal tersebut menjadikan kegiatan pengajian bersama pada kampung ini masih tetap dipertahankan sampai saat ini. Berdasarkan hasil wawancara dengan beberapa responden, kampung ini mengadakan acara mengaji bersama setiap harinya dan berbeda-beda tempat, sehingga masyarakat kampung masih dapat menjalin ikatan kebersamaan satu sama lainnya. Jumlah majelis taklim yang ditemukan oleh penulis dalam periode penelitian ada kurang lebih empat (4) lokasi (gambar 10).

\section{Selasar}

Selasar rumah pada zona dalam menjadi area ruang interaksi sosial yang paling dominan. Masyarakat banyak memanfaatkan ruang interaksi pada area depan rumah mereka baik sekedar berbincang sore, menemani anak-anak bermain, maupun melakukan aktivitas seperti berjualan. Pada waktu penelitian, puncak keramaian aktivitas pada selasar atau koridor dalam adalah pada sore hari terutama waktu weekend. Antusias warga dalam berinteraksi satu sama lain masih terasa kental, sehingga nilai tradisional dari suatu permukiman kampung yang khas dengan interaksi sosialnya dan hubungan antara warga kampungnya masih sangat terasa dan terjalin dengan baik. Hal yang sama ditemukan dalam studi sebelumnya dimana eksistensi kampung masih terasa diakibatkan oleh hubungan interaksi sosialnya yang masih sangat baik antar penduduknya (Igalla, Edelenbos and van Meerkerk, 2020). Berikut adalah beberapa hasil dokumentasi penulis terkait ruang interaksi sosial pada selasar koridor dalam

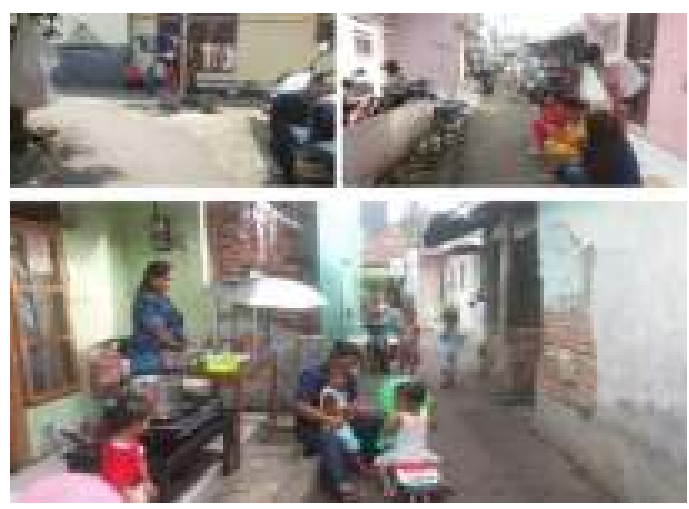

Gambar 11. Ruang Interaksi pada Koridor Dalam Sumber: Dokumentasi Pribadi, 2020
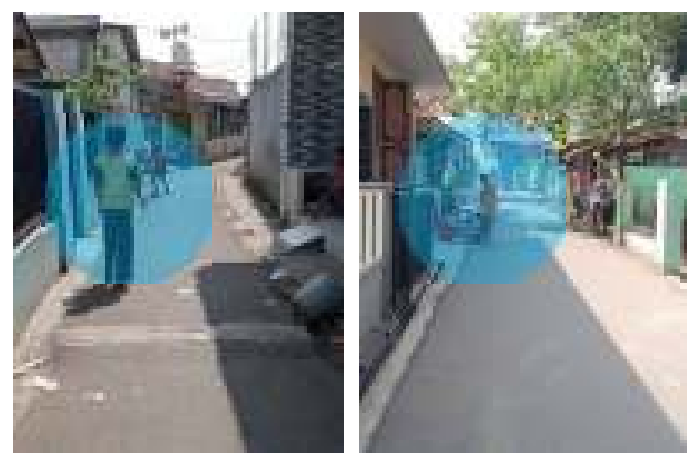

Gambar 12. Aktivitas anak-anak dan remaja pada koridor jalan

Sumber: Dokumentasi Pribadi, 2020

\section{KESIMPULAN}

Keadaan kampung Rumpak Sinang yang terjepit oleh pengembangan kawasan mandiri Gading Serpong memberikan dampak tersendiri bagi kampung baik dari dampak sosial, ekonomi, hingga penggunaan ruang interaksi sosial kampung.

Berdasarkan hasil penelitian dampak ekonomi yang dirasakan oleh masyarakat kampung cukup positif dengan adanya peningkatan lapangan pekerjaan bagi masyarakat kampung, kemudian muncul banyaknya area komersial pada koridor kampung seperti warung makan, kos-kosan, dan sebagainya.

Sedangkan dampak sosial yang dirasakan oleh masyarakat kampung ada yang bersifat positif maupun tidak. Sisi positif dampak sosial dari pengembangan kawasan Gading Serpong terhadap kampung Rumpak Sinang adalah dengan ramainya kampung, maka banyak sekali pendatang dan meramaikan suasana kampung namun konsep pendatang dan warga asli menjadi batasan warga dalam melakukan interaksi. Penelitian menemukan bahwa warga pendatang pada dasarnya kurang menjalin hubungan dengan masyarakat kampung dan hanya memberikan iuran bila ada acara bersama. Kemudian interaksi antara masyarakat kampung dan 
masyarakat Gading Serpong ternyata hanya sebatas pada area komersial dan juga masyarakat Gading Serpong hanya memberikan sumbangan pada acara tertentu.

Selain itu, kepadatan penduduk yang semakin tinggi menyebabkan ruang interaksi semakin sedikit, lapangan yang dahulunya digunakan sebagai lapangan utama ketika melakukan berbagai acara, setelah dijual untuk pembangunan Apartemen M-Town menyebabkan area koridor utama kampung kehilangan ruang interkasi mereka. Peningkatan harga tanah juga menimbulkan dampak sosial bagi warga yang tetap ingin mempertahankan tanah leluhur mereka dari gusuran pihak pengembang sehingga muncul berbagai cerita mitos mengenai susahnya menggusur tanah kampung ini. Isu sosial berikutnya adalah munculnya portal dan pos penjagaan pada area kampung seolah masyarakat kampung mengadopsi kehidupan masyarakat Gading Serpong yang mengarah kepada gated community.

Pada akhirnya, ciri khas bermukim di kampung masih dapat dipertahankan dengan baik oleh masyarakat kampung dan merupakan kekayaan bermukim di Indonesia, seperti yang dijelaskan pada teori social capital, negara dengan ciri khas bermukim seperti ini cenderung mudah maju saat krisis dikarenakan masih terjalinnya hubungan sharing value, sharing identity, dan rasa memiliki yang besar diantara warganya.

\section{DAFTAR PUSTAKA}

Arbi, A., (2017). www.radarbanten.co.id. [Online] diunduh dari: https://www.radarbanten.co.id/kampungrumpaksinang-di-tengah-kepungan-raksasaproperti/ [diakses 2 Desember 2020].

Astari, D. et al. (2015). 'Pola Pemanfaatan Ruang Pada Selamatan Desa di Permukiman Perkotaan', Langkau Betang, 2(ritual tradisi), pp. 42-53. Available at: http://jurnal.untan.ac.id/index.php/lb/article/vie w/13839/12399.

Firman, T. (2004). 'New town development in Jakarta Metropolitan Region: A perspective of spatial segregation', Habitat International, 28(3), 349368. doi: 10.1016/S0197-3975(03)00037-7.

Handa, R. (2017). 'Research Methods for Architecture', Technology Architecture + Design. Routledge, 1(1), pp. 112-113. doi: 10.1080/24751448.2017.1292802.

Igalla, M., Edelenbos, J. and van Meerkerk, I. (2020). 'What explains the performance of communitybased initiatives? Testing the impact of leadership, social capital, organizational capacity, and government support', Public
Management Review. 22(4), 602-623. doi: 10.1080/14719037.2019.1604796.

Kusno, A. (2020). 'Middling urbanism: the megacity and the kampung', Urban Geography, 41(7), 954-970. doi: 10.1080/02723638.2019.1688535.

Leisch, H. (2002). 'Gated communities in Indonesia', Cities, 19(5), 341-350. doi: 10.1016/S02642751(02)00042-2.

Permanasari, E. (2006). 'Traditional Dwellings and Settlements', Working Paper Series Housing Enclaves: Between Reality and Imagination, (195), pp. 1419-1439.

PWC (2019). 'Making Affordable Housing a Reality in Cities', World Economic Forum, (June), pp. 1-60. Available at: ttp://homeguides.sfgate.com/student-hous.

Roger G. Barker.', American Anthropologist. doi: 10.1525/aa.1969.71.6.02a00440.

Turner, J. F. C. (1976). Housing by people: Towards autonomy in building environments. London: Marion Boyars.

Widodo, H. (2019). 'Perencanaan Transportasi Umum Terpadu Pada Kawasan Kota Mandiri (Studi Kasus: Kawasan Bumi Serpong Damai, Kota Tangerang Selatan)', Planners Insight: Urban and Regional Planning Journal, 1(1), pp. 029-034. doi: 10.36870/insight.v1i1.11 